\title{
Potential of Renewable Electricity from Biomass Waste of IIT Roorkee Campus, India
}

\begin{abstract}
Electricity production using conventional energy sources is associated with serious environmental problems like emission of pollutants, global warming and social problems. The world's $\mathrm{CO}_{2}$ emissions are projected to rise from 29.0 billion MT in 2006 to 33.1 billion MT in 2015 and 40.4 billion MT in 2030. This increase in emissions indicates more global warming. The Indian Ministry of New and Renewable Energy (MNRE) has been supporting programs for the development of renewable energy sources which are not only unlimited but environmentally friendly - like biomass, solar, small hydro, wind, etc. If biomass is used sustainably, there is no net carbon emission over the time of a cycle of biomass production.
\end{abstract}

Waste management is an important issue today. To handle the ever growing problem of waste, residents and companies are constantly looking for the best and least expensive methods. Types of waste generated by the Indian Institute of Technology Roorkee (IITR) include kitchen waste, municipal solid waste, sewage waste, and waste cooking oil. By utilizing biodegradable waste out of total waste clean energy can be generated and waste disposal problems solved.

Key words: Kitchen waste, municipal solid waste, waste cooking oil, sewage waste, feasibility study, India

\section{Introduction}

The Solar energy stored in plants and animals as biomass is among the most important resources on the earth and can be converted into various forms of energy by different processes. Biomass wastes such as kitchen waste, municipal solid waste (MSW), sewage waste, etc., contain higher amounts of biodegradables suitable for biogas production via anaerobic digestion, which is less capital investment as compared to other renewable energy sources (Rao, Baral et al 2010;Amigun and Blottnitz 2010). Kitchen waste includes leaves, banana, potato, orange peel, used tea leaves, leftover food, etc. These wastes, if not properly managed, cause problems of disposal and emit considerable amount of $\mathrm{CH}_{4}$ and other toxic gases into the atmosphere as a result of natural biodegradation. Anaerobic digestion of such wastes is an attractive option due to its environmental and economical benefits with the production of biogas. This process consists of three steps: solubilization, acidogenesis and methanogenesis. Each is influenced by environmental factors such as temperature, $\mathrm{pH}$, retention time, loading rates and substrate concentration (Komemoto, Lim et al 2009).

Biodiesel is another attractive alternative liquid fuel that is non-toxic, renewable, has good lubricity and emits lower gaseous emission compared to diesel. It is a substitute for petroleum diesel as is evident by the similarities in fuel characteristics of biodiesel and diesel in terms of flash point, viscosity, cetane number, density and heating value (Zhang, Dube et al 2003). Biodiesel production from waste cooking oil (WCO) is 2-3 times cheaper compared to vegetable oils as feedstocks (Phan and Phan 2003). Waste cooking oil is the quantity of oil remaining after repeated high temperature cooking applications and is conventionally thrown into water streams, thereby, causing water pollution. Biodiesel production from WCO has received increasing attention in recent years and research is going on to improve its performance. (Lam, Lee and Mohamed 2010; Banerjee and Chakraborty 2009; Lin, Hsu and Chen 2011; Liu, McDonald and Wang 2010; Wang, Ma et al 2010; Chen, Xiao et al 2009). Some developed countries have set policies to penalize the disposal of waste cooking oil into drains (Patil, Deng et al 2010). Alternatively, it can be converted to eco-friendly biodiesel for use in Internal Combustion (IC) diesel engines (Demirbas 2009).

The waste water generation in a given area depends on the per capita water demand. The waste water including sewage waste may be treated using sewage treatment plants to generate biogas as by product, and can be used for heat and power generation (Tassou 1988). The treated water can be used for flushing of toilets in houses, floor washing, horticulture, etc.; thereby, reducing the overall demand of drinking quality water that in turn reduces the amount of energy needed to pump the water from the ground. The treated solid waste may be used as good quality manure for agricultural applications.

Another category of waste is municipal solid waste (MSW) obtained from domestic, commercial and industrial (nonhazardous) sectors, with high potential for the production of energy. It consists of biodegradable and non-biodegradable fraction, the percentages of which vary from source to source and activity to activity (Igoni, Ayotamuno et al 2008). Depending on its proximate analysis, the waste can be converted to energy either by biological or thermal processes to produce biogas and steam, respectively, which can be converted to power. The present paper deals with the assessment of potential of kitchen waste, MSW, sewage waste water and WCO available on the Indian In- 
stitute of Technology Roorkee (IITR) campus, sizing of systems and cost of energy. The result indicates that substantial energy may be produced using the wastes available in the campus.

\section{About IIT Roorkee Campus}

Indian Institute of Technology Roorkee (IITR), the premier engineering institute, is located in Roorkee in the Indian state of Uttarakhand, has played a vital role in higher technical education and pursuit of research in the country. The campus has bachelor's hostels for boys and girls, residents for faculty and staff along with different departments. Figure 1 gives the map of the IITR campus showing the locations of various departments, residents, hostels and other settlements.

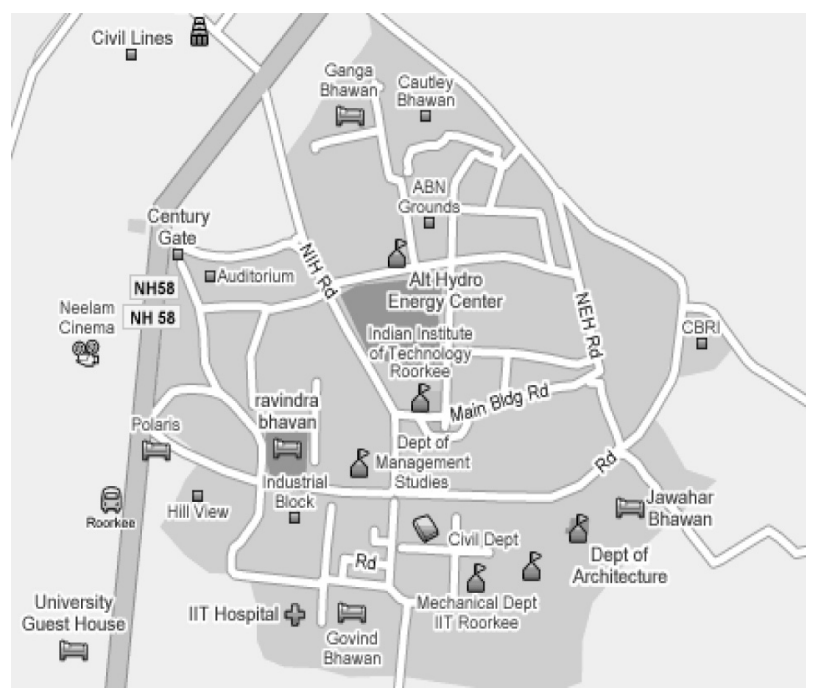

Figure 1. IIT Roorkee Campus

A survey conducted has found that a total of 4,724 students, 5,752 residential families and 1,308 married students are residing in the campus. The family population was calculated assuming 4 members /family. The total population is worked out as 11,784 , rounded to 12,000 . Figure 2 gives the distribution of total population in the campus.

\section{Assessment of Biomass Waste Generation}

The four energy sources are discussed below:

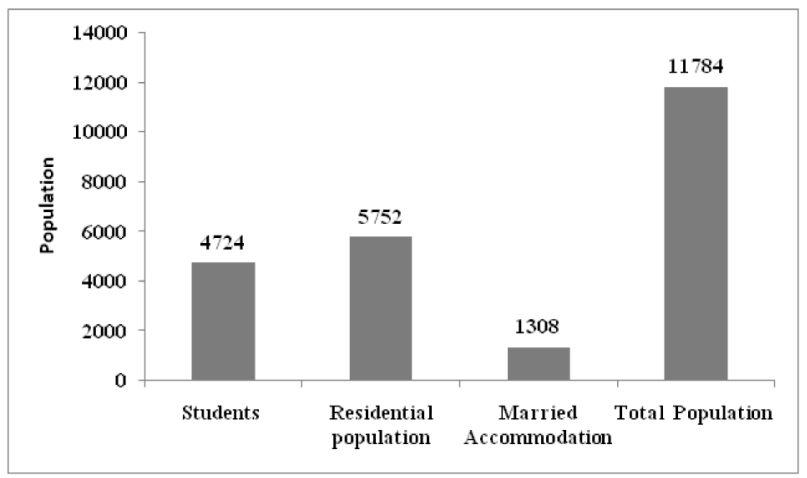

Figure 2. Population of the Institute
- Municipal Solid Waste (MSW) generation

- Waste Cooking Oil (WCO) generation

- Sewage Waste generation

- Kitchen Waste generation

\section{Municipal solid waste generation}

Assuming MSW generation @ $0.5 \mathrm{~kg} /$ person/day (NRCD, MOEF 2010), and considering total population of 12,000, a potential of $6 \mathrm{~T} /$ day is available, which comes to $2190 \mathrm{~T} /$ year (365 days).

\section{Waste cooking oil generation}

Based on the verbal discussions with mess managers of the student hostels, about 36 liters of WCO is available per month totally to 432 liters/year. The containers were placed in each hostel to collect WCO on a monthly basis.

\section{Sewage waste generation}

Considering a population of 12,000 and use of 135 liters per day (LPD)/person of water, the total water consumption comes out as 1.6 million liters per day (MLD) and assuming $80 \%$ of the total water used is available as sewage waste water (MOEF), about 1.3 MLD waste water is generated in the campus.

\section{Kitchen waste generation}

Kitchen waste of hostel messes including vegetable wastes, fruit wastes and leftover food material has been worked out as $0.65 \mathrm{~T} /$ day. Figure 3 gives the kitchen waste availability in student messes contributing largely to the waste. Kitchen waste from other areas such as residences and married hostels is less in quantity and is assumed to be mixed with other wastes. Residential and married hostels kitchen waste is included in MSW generation @ $0.5 \mathrm{~kg} /$ person/day.

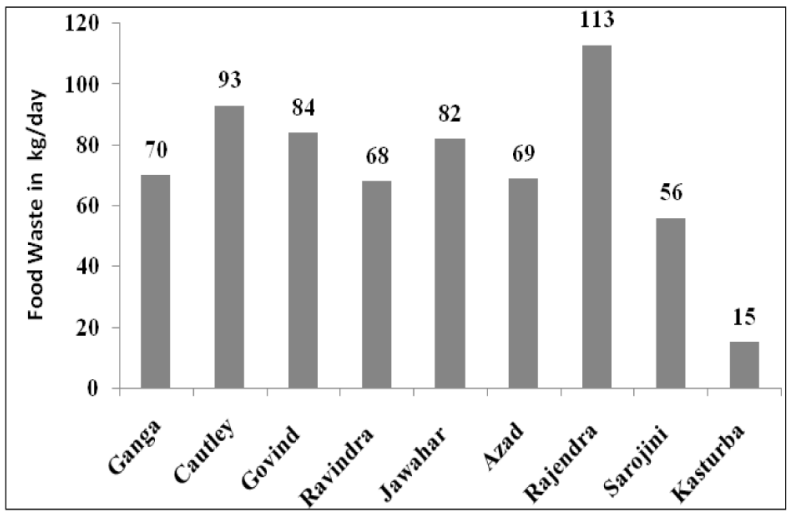

Figure 3. Kitchen Waste Availability in the IITR Messes

Total Waste Potential from IIT R Campus

Table 1 Summaries the total waste generation in the campus for the energy production. 
Table 1. Total waste potential available in the campus

\begin{tabular}{|c|c|c|c|}
\hline & Types of waste & $\begin{array}{c}\text { Quantity/ } \\
\text { day }\end{array}$ & $\begin{array}{c}\text { Quantity/ } \\
\text { year }\end{array}$ \\
\hline 1. & Municipal Solid Waste (T) & 6 & 2190 \\
\hline 2. & Waste cooking oil (L) & 1.183 & 432 \\
\hline 3. & Sewage waste (MLD) & 1.3 & 475 \\
\hline 4. & Kitchen waste $(T)$ & 0.65 & 238 \\
\hline
\end{tabular}

\section{Assessment of Energy Potential}

\section{Biogas from municipal solid wastes}

As mentioned above, about six tons of MSW per day is generated on the campus. Considering 50\% biodegradable fraction, about $3 \mathrm{~T} /$ day solid wastes is available for the production of energy. As per an estimate, $14 \mathrm{Om}^{3}$ gas is produced/T of biodegradable waste (Jain and Sharma 2011) and total biogas generation potential is computed as $420 \mathrm{~m}^{3} /$ day. Assuming the consumption of biogas in IC diesel engine is $0.72 \mathrm{~m}^{3} / \mathrm{kWh}$, a potential of about $583 \mathrm{kWh}$ /day is calculated. For the purpose of generating electricity, biogas fuelled DG generator set of $25 \mathrm{~kW}$ is proposed to consume the gas within 24 hours.

\section{Energy from waste cooking oil}

About 36 liters/month of WCO is available from the campus which can be converted to about 33 liters of biodiesel at conversion efficiency of 90\% (Manadavilli and Sharma, in press). For engine operation, $\mathrm{B}_{100}(100 \%$ biodiesel) and its blends with diesel $\mathrm{B}_{10}$ (example $\mathrm{B}_{10}$ blend means that blend consist of $10 \%$ biodiesel and $80 \%$ diesel), $\mathrm{B}_{20}, \mathrm{~B}_{30}$, $\mathrm{B}_{40}, \mathrm{~B}_{50}$ have been used to operate $2 \mathrm{KW}$ engine. The Break specific fuel consumption (gram/kWh) is given in Table 5 which also gives the potential available from various blends. For calculation of power, the BSFC of $\mathrm{B}_{100}$ has been used as given in Table 3. By considering $B_{100}$ blend $2 \mathrm{~kW}$ engine is proposed for operation of 145 days on the basis of three hours per day operation (Jain 2008).

\section{Biogas from sewage treatment plant (STP)}

Table 2 gives the general physico-chemical properties of sewage waste water and treated water. As stated above, the total sewage waste generation is about 1.3 MLD or $1300 \mathrm{~m}^{3}$. Considering as average biological oxygen demand (BOD) of 160 (mg/liter) and chemical oxygen demand (COD) of 400 ( $\mathrm{mg} / \mathrm{liter}$ ), a total of $286 \mathrm{~m}^{3} /$ day biogas can be generated using the procedure adopted by Metcafe and Eddy (2003).

Table 2. Composition of Raw Sewage and Treated Sewage

\begin{tabular}{|c|c|c|}
\hline Parameter & $\begin{array}{c}\text { Raw Sewage } \\
\text { waste water }\end{array}$ & $\begin{array}{c}\text { Treated waste } \\
\text { water }\end{array}$ \\
\hline $\mathrm{PH}$ & $7-8$ & $6.5-7$ \\
\hline $\mathrm{BOD}(\mathrm{mg} / \mathrm{l})$ & $150-200$ & $10-15$ \\
\hline $\mathrm{COD}(\mathrm{mg} / \mathrm{l})$ & $400-500$ & $30-40$ \\
\hline $\mathrm{TSS}(\mathrm{mg} / \mathrm{l})$ & $200-300$ & $10-20$ \\
\hline
\end{tabular}

Power Generation from Biogas
When biogas is used in $100 \%$ mode, assuming $0.72 \mathrm{~m}^{3} /$ $\mathrm{kWh}$ generation, the power generation is calculated as $397 \mathrm{kWh} /$ day.

Energy produced by engine $=397 \mathrm{kWh} /$ day $=$ $397 \mathrm{kWh} / 24$ hours $=17 \mathrm{~kW}$

Engine capacity proposed $=20 \mathrm{~kW}$

\section{Kitchen waste}

About $0.65 \mathrm{~T} /$ day kitchen waste is generated from the campus. Based on manufacturer's specifications, the biogas plant of one ton per day waste processing capacity is proposed to be installed in one of the hostels that produces about $100-120 \mathrm{~m}^{3} /$ day of methane. Assuming average methane generation $110 \mathrm{~m}^{3}$ /day (Imdaadullah 2008) and methane generated from biogas plant is $0.65 \%$ of the total biogas generated, the total biogas generated is $110 / 0.65$ or $169.23 \mathrm{~m}^{3} /$ day.

Assuming modified IC engine/gas engine operating on 100\% gaseous fuel consumes biogas@0.72 m³ $/ \mathrm{kWh}$ (Manadavilli and Sharma, in press), $235 \mathrm{kWh}$ of electrical energy can be generated per day.

$$
\begin{aligned}
& \text { Energy Produced by engine }=235 \mathrm{kWh} / \text { day } \\
& (24 \mathrm{hrs})=9.8 \mathrm{~kW}, \\
& \text { Proposed Engine capacity }=10 \mathrm{~kW}
\end{aligned}
$$

\section{Total Power Potential}

Energy potential from each source is given in Table 3 . The kitchen waste plant, STP and MSW plant can be sited at one place with separate diesel engine generator (DG) set of different capacity. The kitchen waste plant and STP can also be connected to a $25 \mathrm{~kW}$ engine of MSW plant in order to run engine effectively. When biogas generation is less, a separate $2 \mathrm{~kW}$ DG set operated on biodiesel is proposed for a single department.

Table 3. Energy Potential in Campus

\begin{tabular}{|c|c|c|c|c|}
\hline Sources & $\begin{array}{c}\text { Operation } \\
\text { hours / } \\
\text { day }\end{array}$ & $\begin{array}{c}\text { No of } \\
\text { days to } \\
\text { operate }\end{array}$ & $\begin{array}{c}\text { Plant capac- } \\
\text { ity proposed } \\
(\mathrm{kW})\end{array}$ & $\begin{array}{c}\text { Expected } \\
\text { power gen- } \\
\text { eration } \\
\text { (kWh/year) }\end{array}$ \\
\hline MSW & 24 & 300 & 25 & 180,000 \\
\hline Kitchen waste & 24 & 300 & 10 & 72,000 \\
\hline WCO & 3 & 145 & 2 & 870 \\
\hline Sewage Waste & 24 & 300 & 20 & 144,000 \\
\hline Total Energy & & & & 396,870 \\
\hline
\end{tabular}

\section{Calculation of Cost of Energy}

Cost analyses from kitchen waste, STP and MSW plants are shown in Figures 4 and 5. Based on these analyses, the cost per kWh electricity generation economic is found in all cases. The cost per kWh obtained in STP is highest (Rs 38.6) as the main purpose of STP is to purify the sewage waste and to obtain the manure. The biogas generated as a by-product can be used to produce electricity that can 


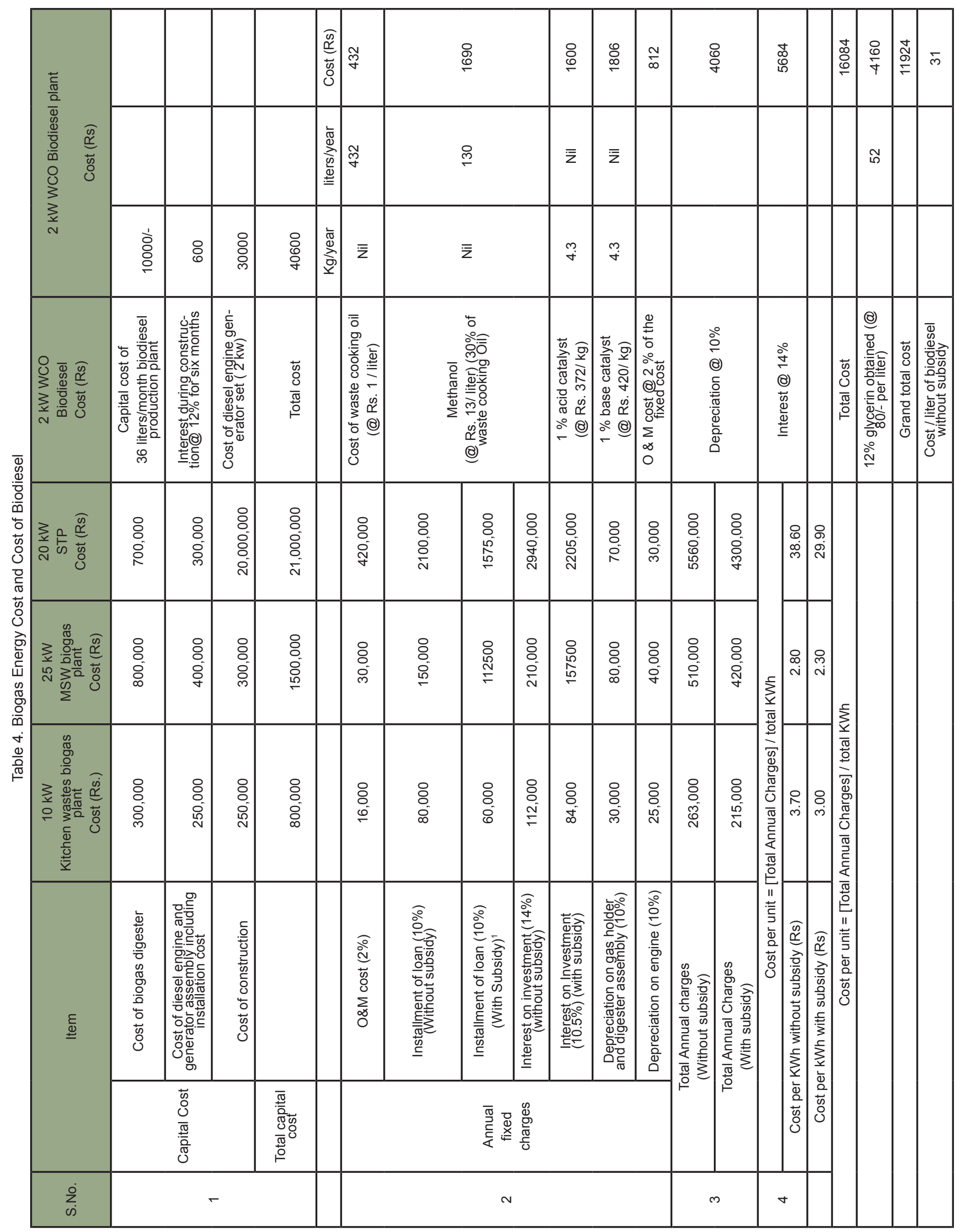


be used in STP plant itself. The analysis assumes that the land will be available free of cost and so land cost has not been considered. The cost analyses have been done with and without subsidy (Dhussa 2010) as shown in Table 4.

It is also calculated that total waste cooking oil from the institute is 432 liters from which about 389 liters of biodiesel could be produced annually. The cost of pure biodiesel B10o is given in Table 4. Table 5 shows that the cost of B10o blend is less than diesel and delivers about 886 units of electricity based on BSFC as calculated by Siddharth Jain (2008). For this purpose an engine of $2 \mathrm{~kW}$ is proposed to run 3 hours/day for 145 days in a year only.

The total power generation all the wastes is $396,870 \mathrm{kWh} /$ year that can be used to reduce the dependency of the institute on grid power in addition to solving the disposal problems of the wastes. The treated sewage waste water is proposed to be used for irrigating of gardens, washing of floors and toilet flushing if required. Total power consumption of the institute from April 2009 to March 2010 is $20,913,100 \mathrm{kWh}$. Total power can be produced from all waste is $396,870 \mathrm{kWh} /$ year and this energy is $2 \%$ of the total power of the institute in a year.

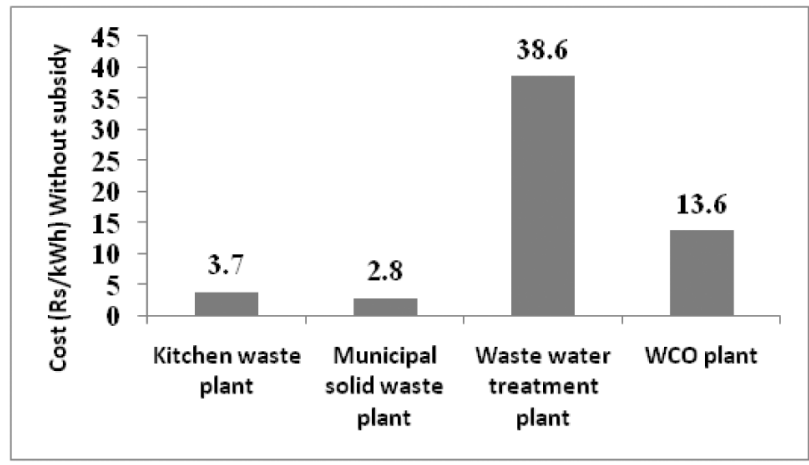

Figure 4. Energy Cost without Subsidy

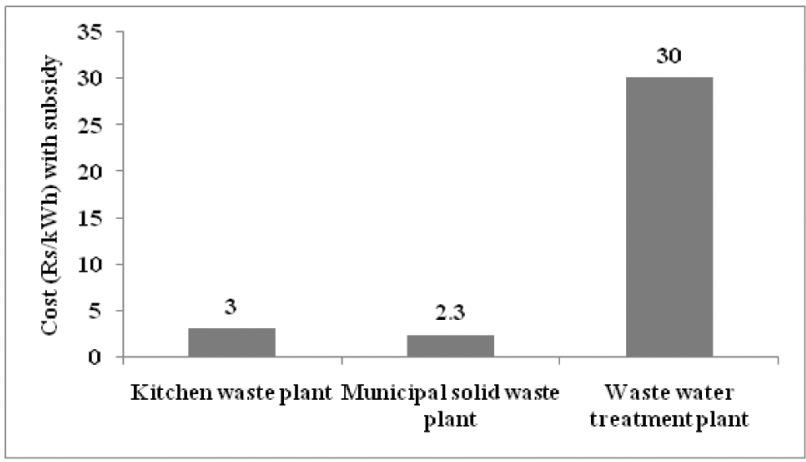

Figure 5. Energy Cost with Subsidy

Table 5. Power Available from Different Biodiesel Blends

\begin{tabular}{|c|c|c|c|c|c|c|c|c|c|c|}
\hline \multirow{2}{*}{$\begin{array}{c}\text { Blends of } \\
\text { biodiesel } \\
\text { with diesel }\end{array}$} & $\begin{array}{c}\text { BSCF } \\
(\mathrm{g} / \mathrm{kWh})\end{array}$ & $\begin{array}{c}\text { Liters } \\
(1)\end{array}$ & $\begin{array}{c}\mathrm{Kg} \\
(2)\end{array}$ & $\begin{array}{c}\text { Cost (Rs) } \\
(3)\end{array}$ & $\begin{array}{c}\text { Liters } \\
(4)\end{array}$ & $\begin{array}{c}\mathrm{Kg} \\
(5)\end{array}$ & $\begin{array}{c}\text { Cost } \\
(\mathrm{Rs}) \\
(6)\end{array}$ & $\begin{array}{c}\text { Total cost } \\
(3)+(6)\end{array}$ & $\begin{array}{c}\text { Power } \\
\text { available } \\
(\mathrm{kWh})\end{array}$ & $\begin{array}{c}\text { Cost/kWh } \\
(\mathrm{Rs} / \mathrm{kWh})\end{array}$ \\
\hline Diesel & 349 & 0 & 0 & 0 & 389 & 338.5 & 15949 & 15,949 & 969.9 & 16.44 \\
\hline $\mathrm{B}_{10}$ & 337 & 38.9 & 36.4 & 1205 & 350.1 & 304.5 & 14354 & 15,559 & 1011.57 & 15.38 \\
\hline $\mathrm{B}_{20}$ & 353 & 77.8 & 72.8 & 2411 & 311.2 & 270.63 & 12759 & 15,170 & 972.8 & 15.59 \\
\hline $\mathrm{B}_{30}$ & 369 & 116.7 & 109.34 & 3617 & 272.3 & 236.7 & 11164 & 14,781 & 937.7 & 15.79 \\
\hline $\mathrm{B}_{40}$ & 373 & 155.6 & 145.7 & 4823 & 233.4 & 203 & 9569 & 14,392 & 934.8 & 15.39 \\
\hline $\mathrm{B}_{50}$ & 381 & 194.5 & 182.2 & 6029 & 194.5 & 169.2 & 7974 & 14,003 & 922.3 & 15.18 \\
\hline $\mathrm{B}_{100}$ & 411 & 389 & 364.4 & 12,059 & 0 & 0 & 0 & 12,059 & 886.6 & 13.6 \\
\hline
\end{tabular}

\section{Conclusions}

Energy from biomass is one of the most efficient and effective options among alternative sources of energy available. The anaerobic digestion of biomass requires less capital investment compared to other renewable energy sources. In this study the potential of biodegradable waste from municipal solid waste (MSW), kitchen wastes, sewage waste and waste cooking oil (WCO) from the IITR campus was assessed followed by the sizing of the conversion system and calculation of the cost of energy of each plant.

The power generation capacity of $25 \mathrm{~kW}$ from MSW, $20 \mathrm{~kW}$ from STP, $10 \mathrm{~kW}$ from kitchen waste, and $2 \mathrm{~kW}$ from WCO has been calculated with the cost of electricity production Rs. 38.60 from MSW, Rs 13.60 from WCO, Rs 3.70 from kitchen waste and Rs 2.80 from WCO. This indicates that WCO, kitchen wastes and MSW wastes available on cam- pus can be potentially converted to electricity. The cost of energy of Rs 38.60 per unit from STP is also worth mentioning, so that if the environmental cost is subtracted the cost of energy will come down considerably as a best utilization of the biogas by-product. A total potential of $396,870 \mathrm{kWh}$ of electricity may be available, which constitutes about $2 \%$ of the total power purchased by the ITTR from the utility network. The results of our study are encouraging in the sense that energy conservation measures including environmental protection should be given utmost emphasis in future.

Nitesh Dutt is a Mechanical Engineer and an M.Tech second year student of Alternate Hydro Energy System (AHES). He worked on the Assessment of Energy Potential of IIT, Roorkee, during his project.

Corresponding address: mech.nitech@gmail.com 
M.P.Sharma, PhD, has been working as Associate Professor at Alternate Hydro Energy Centre, Indian Institute of Technology, Roorkee (India), since the last 25 years. His areas of research are renewable energy with special reference to Modeling of IRES, hybrid energy systems, induction generators, environmental impact assessment (EIA) of renewable energy projects, energy and environment conservation, conservation of water bodies, water quality assessment, biodiesel production and utilization. Corresponding address: mpshafah@iitr.ernet.in or mahendrapal.sharma@gmail.com

\section{Acknowledgement}

The authors acknowledge the financial support from Ministry of Human Resource Development (MHRD), Govt. of India, in the form of scholarship to carry out this work.

\section{References}

Amigun, B. and H.V. Blottnitz, 2010, Capacity-cost and location-cost analyses for biogas plants in Africa, $R e$ sources, Conservation and Recycling 55:63-73.

Banerjee, A. and R. Chakraborty, 2009, Parametric sensitivity in transesterification of waste cooking oil for biodiesel production: A review, Resources, Conservation and Recycling 53:490-497.

Chen, Y., B. Xiao, J. Chang, Y. Fu, P. Lv, P. and X Wang, 2009, Synthesis of biodiesel from waste cooking oil using immobilized lipase in fixed bed reactor, Energy Conversion and Management 50:668-673.

Demirbas, A., 2009, Biodiesel from waste cooking oil via base-catalytic and supercritical methanol transesterification, Energy Conversion and Management 50:923927.

Dhussa, A., 2010, Strategies and Policies to Overcome Barriers in Implementation of Anaerobic Digestion, Delhi: Ministry of New and Renewable Energy, Government of India. URL: www.globalmethane.org/ expo/docs/postexpo/ag_dhussa.pdf

Igoni, A.H., M.J. Ayotamuno, C.L. Eze, S.O.T. Ogaji, and SW.D. Probert, 2008, Designs of anaerobic digesters for producing biogas from municipal solid-waste, $A p$ plied Energy 85:430-438.

Imdaadullah, S.A.S., July 2008,Saleem India Blog on "Kitchen waste to energy $0.5 \mathrm{~T}$ capacity plant". URL: www.saleemindia.blogspot.com/2008/07/kitchen-waste-to-energy-05-ton-capacity.html

Jain, S. and M.P. Sharma, 2011, Power generation from MSW of Haridwar city: A feasibility study, Renewable and Sustainable Energy Reviews 15:69-90.

Jain, S., 2008, Performance Evaluation of IC Engine using Biodiesel from Different Fuel Sources, M.Tech thesis, Roorkee: Alternate Hydro Energy Centre, Indian Institute of Technology.

Komemoto, K., Y.G. Lim, N. Nagao, Y. Onoue, C. Niwa and T. Toda, 2009, Effect of temperature on VFA's and biogas production in anaerobic solubilization of food waste, Waste Management 29:2950-2955.

Lam, M.K., K.T. Lee and A.R. Mohamed, 2010, Homo- geneous, heterogeneous and enzymatic catalysis for transesterification of high free fatty acid oil (waste cooking oil) to biodiesel: A review, Biotechnology Advances 28:500-518.

Lin, Y.C., K.H. Hsu, K.H. and C.B. Chen, 2011, Experimental investigation of the performance and emissions of a heavy-duty diesel engine fueled with waste cooking oil biodiesel/ultra-low sulfur diesel blends, Energy 36:241-248.

Liu, S., T. McDonald and Y. Wang, 2010, Producing biodiesel from high free fatty acids waste cooking oil assisted by radio frequency heating, Fuel 89:2735-2740.

Mandavilli, S.N.V.R.A. and M.P. Sharma, in press, Biodiesel from waste cooking oil for power generation, Journal of Indian Water Resources Society.

Metcalf \& Eddy, Inc., 2003, Wastewater Engineering Treatment and Reuse, revised edition by G. Tchobanoglous, F.L. Burton and H.D. Stensel, Delhi: Tata McGraw-Hill.

MOEF (Ministry of Environment and Forests), Manual on Norms and Standards for Environment Clearance of Large Construction Projects, Delhi: Ministry of Environment and Forests. URL: www.envfor.nic.in/divisions/iass/Construction_Manual.pdf.

NRCD(National River Conservation Directorate), MOEF (Ministry of Environment and Forests), 2010, Guidelines for Preparation of Project Reports Under $\mathrm{Na}$ tional River Conservation Plan and National Ganga River Basin Authority, prepared by Alternate Hydro Energy Centre, Indian Institute of Technology, Roorkee, Delhi: Ministry of Environment \& Forests National River Conservation Directorate. URL: www.moef.nic.in/downloads/public-information/ Guidelines\%2ofor\%20Report\%20Preparation\%20 under\%20NRCP\%20NGRBA\%20Dec\%202010.pdf

Patil, P., S. Deng, J.I. Rhodes and P.J. Lammers, 2010, Conversion of waste cooking oil to biodiesel using ferric sulfate and supercritical methanol processes, Fuel 89:360-364.

Phan, A.N. and T.M. Phan, 2008, Biodiesel production from waste cooking oils, Fuel 87:3490-3496.

Rao, P.V., S.S. Baral, R. Dey and S. Mutnuri, 2010, Biogas generation potential by anaerobic digestion for sustainable energy development in India, Renewable and Sustainable Energy Reviews 14:2086-2094.

Tassou, S.A., 1988, Energy Conservation and Resource Utilisation in Waste-Water Treatment Plants, Applied Energy 30:113-129.

Wang, Y., S. Ma, M. Zhao, L. Kuang, J., Nie and W.W. Riley, 2010, Improving the cold flow properties of biodiesel from waste cooking oil by surfactants and detergent fractionation, Fuel 90:1036-1040.

Zhang, Y., M.A. Dube, D.D. McLean and M. Kates, 2003, Biodiesel production from waste cooking oil: 1. Process design and technological assessment, Bioresource Technology 89:1-16. 